\title{
ECO-LABELING AND INTERNATIONAL TRADE AGREEMENTS: THE CASE OF MARINE STEWARDSHIP COUNCIL CERTIFICATION FOR INDONESIA'S SHRIMP POTENTIAL MARKET
}

\section{Eco-Labeling dan Perjanjian Perdagangan Internasional: Kasus Sertifikasi Marine Stewardship Council untuk Pasar Potensi Udang Indonesia}

\author{
Umi Karomah Yaumidin', Oman Zuas ${ }^{2}$ \\ ${ }^{1}$ Research Centre for Economic - LIPI, Widya Graha Building $5^{\text {th }}$ floor, \\ Gatot Subroto Street No.10, Jakarta, 12190, Indonesia \\ ${ }^{2}$ Centre for Research and Human Resource Development - National Standardizaion Agency of \\ Indonesia (BSN) Kawasan PUSPIPTEKS Building 420, Serpong, Tangerang Selatan, \\ Banten, 15314 Indonesia \\ Email: yaumidinuk@gmail.com
}

Received: 18/11/2020; Received in revised form: 21/05/2021; Accepted: 19/11/2021; Available online: 24/12/2021

\begin{abstract}
Abstrak
Artikel ini membahas analisis biaya dan manfaat dari Marine Stewardship Council (MSC) untuk ekspor udang putih (Litopenaeus vannamei) dan udang windu (Penaeus monodon) dari Indonesia. Penerapan MSC pada produk perikanan memang tidak wajib, tetapi dapat mempengaruhi kinerja eskpor Indonesia. Perhitungan analisa biaya dan manfaat untuk proyek MSC menggunakan beberapa pilihan yang dihitung ke dalam empat komponen analysis yang terpisah (Proyek, Privat, Efisiensi, dan kelompok penerima manfaat). Dengan menggunakan data tahun 2018 dan jangka waktu investasi selama 20 tahun, kajian ini membandingkan hasil investasi yang menerapkan standard MSC dengan hasil investasi yang tidak menerapkan standard MSC dengan mempertimbangkan hambatan dari biaya perdagangan internasional. Secara keselurahan, studi ini menunjukkan bahwa the Net Present Values (NPVs) and Internal Rate of Returns (IRRs) bersifat konsisten untuk semua pilihan analysis. Studi ini juga menyimpulkan bahwa berdasarkan hasil dari analisis pasar, Amerika Serikat adalah pasar yang menjanjikan bagi produk udang Indonesia yang berlabelkan MSC. Pemerintah Indonesia akan menikmati 13\% kenaikan pendapatan dari pajak keuntungan bisnis tersebut, meskipun proyek ini tidak memberikan dampak perubahan kepada tenaga kerja tidak terampil. Oleh karena itu, studi ini merekomendasikan pemerintah Indonesia untuk mempromosikan program MSC untuk perikanan berkelanjutan, terutama bagi peningkatan kinerja eskpor udang Indonesia.
\end{abstract}

Kata Kunci: Kebijakan Perdagangan, Perikanan Tangkap, Keberlanjutan, Cost-Benefit Analysis

\begin{abstract}
This paper discusses the cost and benefits analysis of the Marine Stewardship Council (MSC) for Indonesia's exports of white shrimp (Litopenaeus vannamei) and tiger prawns (Penaeus monodon). The MSC adoption is voluntary, but it is likely to affect the performance of Indonesia's exports. We use several options applied separately in four components analysis in performing the social cost and benefit analysis (Project, Private, Efficiency, and Referral Group). Using the 2018 data and a 20-year investment period, this study compares the investment results applying the MSC standard with the results without investing in the MSC procedures concerning the trade cost barriers. Overall, the results reveal that the Net Present Values (NPVs) and Internal Rate of Returns (IRRs) are consistent for all options in all feasibility
\end{abstract}

https://doi.org/10.30908/bilp.v15i2.539

Published by Trade Analysis and Development Agencies, Ministry of Trade. This is an open access article under the CC BY-NC-SA 4.0 license (http://creativecommons.org/licenses/by-nc-sa/4.0/) 
component analyses. It concludes that based on market analysis, the US market is the promising market as a primary export destination for Indonesian shrimp products with MSC label. The government will benefit by $13 \%$ from profit taxes, while this project does not affect unskilled labor benefits. Therefore, it recommends that the Indonesian government take more action to promote the MSC program for sustainable fisheries and boost shrimp export performance.

Keywords: Trade Policy, Capture Fisheries, Sustainability, Cost-Benefit Analysis JEL Classification: F13, Q22, Q56, H43

\section{INTRODUCTION}

In 2018 Indonesian fisheries have contributed about 22.9 million tons to global fish stock. It is worth noting that shrimp production is one of major Indonesia's fisheries export. From both capture fisheries and aquaculture farms, shrimp production has reached over 1.2 million tons per year, contributing about $7.45 \%$ to total Indonesia's fishery export (Ministry of Marine Affairs and Fisheries, 2019). Moreover, Indonesia's shrimp capture production is the second-largest producer in the world, after China. It supplies for the United States of America, Japan, European Union countries, ASEAN, and China markets.

Even though the high export growth has been maintained during 2015-2018, sustainable shrimp management in Indonesia still faces several problems. At the production site, many internal conflicts are generated, most of which involve small-scale fisheries (Gillett, 2008). Notably, the structure of the shrimp industry is complex and problematic. The fact that there are many boats, various types of fishing gear, and illegal fishing and trade activities puts marine biodiversity at risk. Moreover, insufficient statistical information and inadequate law enforcement make it more challenging to resolve some existing environmental issues in fisheries.

Concerning international trade, the effects of subsidies in developed countries related to environmental measures may impede opportunities for developing countries (DCs) to access the market. For instance, European Union requires sanitary (human and animal health), and Phytosanitary (plant health) measures for an imported product from DCs. This regulation is a technical barrier for Indonesian shrimp export to the European market and most developed countries (Wijen \& ChiroleuAssouline, 2019). Furthermore, Ecolabel began to emerge across developed countries in the early 1970s. The induction of German "Blue angel" in 1977 , or the EU introduced the idea of supranational Eco-labeling in 1987 
(Melser \& Robertson, 2005). Eco-label was recognized internationally by implementing ISO 14020 in 1989, and the most famous one is Codex Alimentarius Commissions for intergovernmental standards. Ecolabeling is proposed to give market incentives to ensure seafood products are produced in environmentally friendly procedures and in line with food safety standards. Most DCs could not deny it since this regulation complies and is consistent with the WTO agreement. Fisheries eco-labels are being developed through government assessment in the regional context. However, it needs a more comprehensive assessment that includes fisheries' stakeholders to be involved in reaching international markets. Likewise, in Nordic countries, they operate four eco-labels which are mostly under non-government assessment. These fisheries eco-label include the Marine Stewardship Council, the Friend of the Sea, Natural, and the Marine Aquarium Council.

Eco-label on fish products is the initiative to set an environmentally friendly standard through certain certifications and remarkable labels. Ecolabelling schemes can be classified into 3 categories (Wessells, Johnston, \&
Donath., 1999.). First-party labeling, where individual companies set their own product standard or doing selfdeclaration that their product produces using a particular environmental principle. Industries or associations establish Second-party labeling schemes for their members' products. Third-party labeling schemes are initiated by the public or private as an independent agent.

In this regard, the third-party labeling schemes can refer to the work of the Worldwide Fund for Nature (WWF) and Unilever to establish the Marine Stewardship Council (MSC) in 1999 and the Aquaculture Stewardship Council (ASC) in 2010. The MSC standard is presented as a series of auditable requirements designed to be used by fishing companies to demonstrate the implemented system to provide high-quality and responsible management of fish and seafood caught. Under this flagship, a chosen third-party organization certifies fisheries that they widely use responsible fishery management and meet the standard. The MSC principles follow the FAO Code of Conduct for Responsible Fisheries (CCRF) in determining the basics standard. These international principles and codes are 
adapted to suit the specific demand of intensive and extensive production systems at the national level.

For a diverse country like Indonesia, the MSCs are further adapted to the range of production systems found in different regions and used by local governments, companies, and NonGovernment Organizations (NGOs). These actors enact a translation process from the global concern into a local context to increase the likelihood of adoption and subsequently the performance of capture shrimps' fisheries.

Today, 312 fisheries from 30 countries have been certified, and more than 68 fisheries are under assessment, including Indonesia (Lajus, Stogova, \& Keskitalo, 2018; Tsutsui et al., 2015). The Indonesian government, in collaboration with producer, WWF Indonesia, WWF Japan, and the supplier Nichirei Fresh Inc., created a success story to certify Black Tiger shrimps with ASC standard in 2012 (Aquaculture Stewardship Council, 2017). This achievement triggers the fishing company to certify its product under MSC procedures.

In 2017, an Indonesian company had applied for an MSC certificate for Banana and Tiger prawns. Based on the
MSC guideline, the certification process takes more than seven years, from the pre-assessment stage to the final stage (stage 1 to 5 ), to complete all the requirements. The pre-assessment is the process of identifying any potential challenges for certification. In this first stage, a fishery may address issues that need improvement before proceeding with a full assessment. The next step will give opportunities for stakeholder input and peer review to participate in the assessment. It takes $8-18$ months to propose any improvement project. The third stage is the implementation of that proposal. It takes at least five years for a fishery or company to fulfill the improvements required as a condition of certification (Marine Stewardship Council, 2021). Unfortunately, the firm has failed to follow the MSC procedure at the third stage. It leads to the company reapplying and follow the process starting from the beginning, or the company will never get the blue label for its products.

Hence, calculating the cost-benefit of the MSC project on capture shrimp fisheries is required to avoid potential risk or market failure. The cost-benefit estimate is beneficial not only for the company to optimize their investment but also for the stakeholders 
(government,

non-government

organizations, local communities, and other communities) who seek mutual benefits to engage in this project. However, this study is scant in the literature because the company usually does cost and benefit calculations. The cost-benefit information is strictly confidential and closed to the public, while such information is important not only for the company but also for decision-makers. Therefore, in this paper, we give brief information on how the non-tariff barrier (NTB) measure can affect the performance of capture fisheries in Indonesia through the costbenefits analysis of MSC adoption on capture shrimps.

The implementation of MSC may be contra-productive for improving the trade competitiveness of Indonesian fisheries. Small-scale shrimp catchers dominate the fishers' majority. They are less educated on preserving the environment around their fishing ground area to comply with an international standard on sustainable fisheries. Fishers applied irresponsible fishing practices to increase export volume, but they neglect its effect on sustainable marine resources. Notably, the fishing ground areas are being reduced slowly, indicating that overfishing has occurred in Indonesia. In line with this context, the implication of MSC will give more comprehensive opportunities for exporters from the developed country as the leading players in the global fish market. On the other hand, countries having difficulties meeting MSC requirements will be left behind in this market.

However, it is not always the case that consumers prefer to choose an ecolabeling product. For instance, a mismatch between those food safety and marine sustainability delivered by certification and consumers' preference has been a common issue in Japan. Current studies reveal that Japanese consumers prefer to consume more domestic products than imported products. They are more concerned about food safety and quality, but they do not care about sustainability issues being promoted in fisheries certification (Blandon \& Ishihara, 2021). This issue challenges the performance of the export of seafood from DCs. Therefore, to compete with producers from developed countries, they need support from local government and investors, particularly to be able to meet the international standard on quality and safety of seafood products. 
The purpose of this paper is to compare the results of cost-benefit analysis for wild-caught shrimp fishermen who participate in the MSC project and meet its standard with those who do not participate in the project. Despite the main purposes of ecolabeling to protect consumers from unhealthy food and preserve sustainable fisheries, the presence of MSC standard is viewed as an NTB measure for imported seafood products from developing countries. This measure imposes production costs because the fishers or companies must invest in environmental improvement as suggested by the MSC assessment. The range of this cost varies, depending on the level of environmental damage to pursue sustainable marine resources, the complexity of the fishery production process, the availability of information, and stakeholder involvement. It is predicted that the cost of MSC investment is about USD 15,000 to 120,000 (Christian et al., 2013). The issue between preserving fish stock and meeting consumer demand for seafood products is difficult to address in one policy. The bilateral trade agreement between Indonesia and its trading partners is one of the alternative solutions to minimize the negative impact of trade barriers. In doing so, cost and benefit analysis of the specific project such as MSC adoption is essential to help identify the potential loss from such investment. Thus, a dilemmatic issue on food security and environmental degradation can be managed. This study also provides an optimal allocation of shrimp trade among Indonesian trading partners.

\section{Overview of the Marine Stewardship} Council (MSC) System in Indonesia

The Marine Stewardship Council (MSC) is one of the Eco-label forms designed based on market mechanisms to persuade consumer decisions and manage procurement regulations of retailers (Bellchambers, Phillips, \& Pérez-Ramírez, 2016). The MSC recognizes and rewards any effort taken to protect future seafood supplies and to preserve oceans.

Initially, this policy was implemented in European countries to facilitate the growing consumer awareness on the sustainability of marine resources and fishing practices. To date, this type of eco-labeling has been implemented worldwide as the component of seafood marketing strategies, political tools to validate government processes and good practices of marine resources 
management (Bellchambers et al., 2016; Lajus et al., 2018; Le Manach, Jacquet, Bailey, Jouanneau, \& Nouvian, 2020; Ponte, 2012).

Historically, the MSC label has been proposed before the launch of the Aquaculture Stewardship Council (ASC), but in Indonesia's shrimps, ASC standard has been adopted earlier than the MSC standard. These two sustainable certifications are the same in terms of the goal, but they differ in focus and principles. Hence, both apply and establish requirements standards to measure sustainable fisheries for both capture fishing and aquaculture farming. Notably, any proportion of ASC and MSC certified seafood could be mixed in the same product, with both labels being used at any stage in the supply chain. Under some conditions, the chain of custody is displayed in the pack. The ASC logo and MSC eco-label are of the same size and not modified.

The MSC certification focuses more on keeping the ocean fish-stock, respecting habitats, and ensuring those who depend on fishing for maintaining their livelihoods (Ponte, 2012). The blue MSC label in seafood products means that the product has been assessed and certified. Notably, the product has passed the wild, traceable, and sustainable requirements. For instance, Indonesian Yellow Tuna fish is the first case of MSC labeled in early 2020.

Interestingly, this sustainable fishery management operation includes about 123 small-scale fisheries in Buru islands (GRO, 2020; Ponte, 2012). However, this eco-labeling takes a long process for shrimp capture, particularly to fulfill the requirement on areas for improvement. Companies are encouraged to develop action plans to meet the MSC standards, but given the current state of marine resources, a blue label is still far away from being achieved.

The use of trawl gear since 1967 has had negative implications on fish stock and destroy marine resources (Gillett, 2008). To restore blue marine resources and increase fish stock in the sea, adopting the MSC standard is promising. However, in any processing stage, MSC-related marine-governance procedures suffer from a limited understanding of ecosystem functioning and involve high uncertainties. These challenges somehow lead to different outcomes even if the target species and fishing methods are very much alike (Toonen \& Mol, 2013). 
Lessons Learned from The Failure of Getting MSC Label: The Case of South Kalimantan Shrimps Fishery Improvement Project

PT Sekar Laut Tbk has been recorded as a Fishery Improvement Project (FIP) member in getting an MSC certificate by 2020 . The company has registered as manufacturing of shrimps' crackers ("Finna" as a trademark), which has the main office in Surabaya, East Java Province. Prior to applying as a FIP member, this company had won the Seafood Savers award from World Wildlife Fund (WWF) Indonesia in 2017. To continue its corporate social responsibility program, the company intended to achieve MSC label and certification by implementing sustainable and responsible shrimp harvesting practices for the fishers in Kotabaru district (South Kalimantan province). WWF Indonesia gave assistance and monitor company activities to conduct MSC principles. The support is a part of WWF mission that is "assisting Indonesia to process natural resources that abound intending to provide healthy nutritious food and

Fishery Progress.org is one-stop-shop information on the progress of global fishery improvement projects. It makes tracking quality" by improving company supplier fishing practices.

In the MSC assessment process, a company working together with the supplier (the fishermen in Kotabaru) has targeted white prawn (Penaeus indicus) and banana prawn (Penaeus merguiensis) to be certified by MSC. These shrimps are caught using a trammel net on a vessel often operated by two people. The objectives of this effort are (i) to meet the MSC standard and achieve MSC certification by 2020; (ii) to minimize the shrimp's fishery's impact on the environment; (iii) to promote full compliance with fishery regulations; (iv) to promote transparency of information on stock status and traceability; and (v) to strengthen community-based management systems. These actions followed the instruction of the MMAF regulation No. 2/2015, a trawl and seine net ban in WPP-RI (Wilayah Pengelolaan Perikanan Republik Indonesia Indonesia Fisheries Management Area) (Ministry of Marine Affairs and Fisheries, 2015).

However, according to Fishery Progress.org, ${ }^{1}$ the project on Indonesia

progress more efficient, consistent, and reliable for business. (www.fisheryprogress.org) 
South Kalimantan shrimp-trammel net ended in February 2019. It indicates that a company failed to meet the requirements for progress reporting specifically, failing to submit reports for one year or failing to report at least one stage 4 (improvement in fishing practice or fishery management) or stage 5 (improvement on the water) outcome within three years. The assessment process in stage 3 (implementation) suggested that a company and its partner (fishers in Kotabaru) have to address the lack of data for shrimps' stock and improve fisheries management regulations.

Therefore, to minimize the potential loss of this investment, the company is supposed to take lessons learned from previous experiences. Hatanaka (2010a) states that the shrimp project in rural Indonesia is designed based on techno-scientific norms representing Western values instead of local wisdom. The difficulties in pushing a western model may arise from developing, communicating, and enforcing a standard on sustainable fisheries due to differences in the cultural and structural system.

She also exercises that the failure of the Transnational Alternative Agrifood Networks (TAAFNs) project is driven by participation and acceptance of local fisher on the new ideas brought from foreign countries (Hatanaka, 2010b). By examining a trade network between Indonesia and Swedish in the organic shrimp trade, she also concludes that the asymmetry in power between southern and northern producers remains because a fair and democratic building of TAAFNs was not delivered smoothly (Hatanaka, 2010b). Hence, she recommends that the Indonesian government seek trade practices that are more eco-friendly and socially responsible for reducing the gap between the north and south producers.

Correspondingly, the company and government should consider whether this standard is apt to the Indonesian fisheries characteristics. Implementing MSC standards may provide a disproportionate picture of small-scale fisheries, as investing in MSC projects requires a large amount of capital. Although the small-scale fisheries are the majority in the fisheries industry, only several firms have monopolized offfarming practices related to marketing activities (Le Manach et al., 2020) . Therefore, co-management between the large multinational company, the government, and fishing communities is needed to conserve fishing resources. It 
implies that precautionary conditions to follow MSC procedures should involve the artisan (the small-scale and traditional) fisheries in getting the certification process. Improving the value chain through mutual agreement and strong cooperation between seafood industries and the artisan fishers probably could improve export performance as well as sustainable marine resources.

\section{METHODS}

As we mentioned earlier, the adoption of eco-labelling for shrimp capture in Indonesia was limited. Neither fishers nor companies were successful in getting this certificate and label. Accordingly, lessons learned from the failure of PT. Sekar Laut, which runs a CSR (Corporate Social Responsibility) program by helping fishers to get MSC labelling, suggest that the firm did not consider the burden cost of improving sustainable marine resources in this case. Hence, it is crucial to provide an example of how to conduct cost and benefit analysis on fisheries projects by including the MSC labeling aspect in the analysis. In doing so, we examine the cost and benefits for Indonesian fishermen participating in the MSC project for wild-caught shrimp versus continuing to use traditional fishing method. This paper assumes that any organizations (government, nongovernment, company, fishers, and communities) can apply a proposal to get a blue label from MSC. However, our data are limited to shrimp stocks in West Kalimantan, which are more dominated by small-scale fishers. Data on output stock and inputs are obtained from the Indonesian Ministry of Marine Affairs and Fisheries (MMAF). FAO (Food and Agriculture Organization) Marine and Fisheries database provide data for world shrimp production.

Regarding the shrimps' export for international trading between Indonesia and trading partners, information on tariff, duties, and bilateral or multilateral agreements are needed. World Bank and World Trade Organization (WTO) officially publish tariff and duties data that is required by each trading partner country. This information is available online at TRAINS database. The original sources of this database come from UNCTAD (United Nation Conference on Trade and Development). Another important information is the prices of shrimp in the international markets. Information on prices varies from country to country and across time. If the data are obtained from multiple publications, the data may have some 
biases for analysis. It is preferable to take data on prices from one credible source to reduce the bias of data. International Trade Centre (ITC) provides monthly and quarterly price data from each export destination country. The average shrimp's price in 2018 is used as an initial value of the investment.

For detailed information related to the technical operation of shrimp fishing, we interview an expert and some fishers to get the real value of operational cost and other costs in this regard. We have researched the possibility of MSC being adopted for Indonesia's marine conservation in 2012. To get this paper's aim, we updated the information from the current statistic database and fishing operation on that project to the current situation.

\section{Empirical Analysis}

This study calculates the social cost and benefits of the MSC system of Indonesian shrimp production. It applies an extrapolation technique to cover a comparable basis across potential trading partners for Indonesia shrimp's export. The traditional measurement of cost-benefit analysis is a process of identifying, measuring, and comparing the benefits and costs of an investment project or program.
The cost-benefit analysis assumes that the cost of the project is measured as an opportunity cost of which would have been produced by the land (fishing ground), labor, capital, and other materials inputs of the fish stock enhancement project. However, this physical project may include the changes in public policy such as the tax or subsidy and regulatory regime. This paper provides cost-benefit analysis with and without MSC investment in this exercise, so decision-makers can choose two alternatives: undertake the project or do not undertake the project. In reality, the variants of project decisions are probably available more than two options, but it assumes only two options regarding reach sustainable marine resources purposes. Decisionmakers should consider the net benefits of the project; all values have to be converted to values at a common point in time, usually at the present time.

The net present value (NPV) is a measure of the extent to which the MSC is a better $(N P V>0)$ or worse $(N P V<0)$ use of scarce resources than the next best alternative. The traditional form of cost-benefit analysis calculates the aggregate net benefits of a project irrespective of which groups are 
affected. It is also called an efficiency analysis.

The projects undertaken by both the public sector and private projects, like as third-party labeling scheme under MSC certificate, need to be appraised to determine whether they represent an efficient use of resources. Importantly, the complete sets of project effects are often distinguished by the social cost and benefits aspect from the project's purely private cost and returns (Campbell \& Richard P.C. Brown, 2016). In this study, the cost-benefits analysis is also used to appraise the efficiency of private projects from a public interest viewpoint.

In the literature, efficiency analysis is useful to know how the project meets the efficiency point, particularly for production and operational cost (Adler \& Posner, 1999; Seekao \& Pharino, 2018). Following Campbell and Richard P.C. Brown (2016), an efficient cost-benefit analysis can consider different viewpoints. First, the perspective of private analysis is summarizing the benefits and costs to the owners of the shareholders in the firm. Second, the referent and non-referent group point of view. The referent group is a subset of those affected by the project, while this project indirectly influences the non- referent group. The cost-benefit analysis report summarizes all benefits and costs to the referent group, consisting of those entities whose benefits and cost matter in coming to a decision about MSC investment. This group includes the provider of the firm's loan (the domestic bank) and the firm's tax payment (the government and community). The net benefit of the MSC project to the nonreferent group members (the firm's equity holders) is the NPV measured by market prices. However, in this paper, pollution of the rise sea level is ignored as market prices cannot measure it.

\section{RESULT AND DISCUSSION}

\section{The Performance of Indonesia's Shrimps Export}

Shrimp is considered as one of the Indonesian most valuable fishery exports. Compared to all seafood products, wild-caught shrimp is the largest contributor to foreign exchange earnings. In 2016, Indonesian farming and capture shrimps contributed about $12.29 \%$ to global shrimp production (Kasim, 2019). Nationally, in 2018 it contributed around $2.6 \%$ to Gross Domestic Product (GDP). Apparently, in that year, live shrimp's production was more than 300 thousand tons, equal to a quarter of total shrimp production in the country. 
Figure 1 presents the production distribution of wild-caught shrimps by Province. North Sumatera, West Kalimantan, and East Java are the three largest shrimp producers. Notably, shrimps fishing in those provinces are dominated by smaller-scale operation, while large-scale companies are commonly operated their trawlers in the
Arafura Sea (the biggest area of shrimps fishing ground) (Resosudarmo \& Kosadi, 2018). In this area, the Tiger prawn (Penaeus monodon) is the largest commodity that is predicted to have total annual production across Indonesian seas is about 180.000 tons (World Wildlife Fund, 2015).

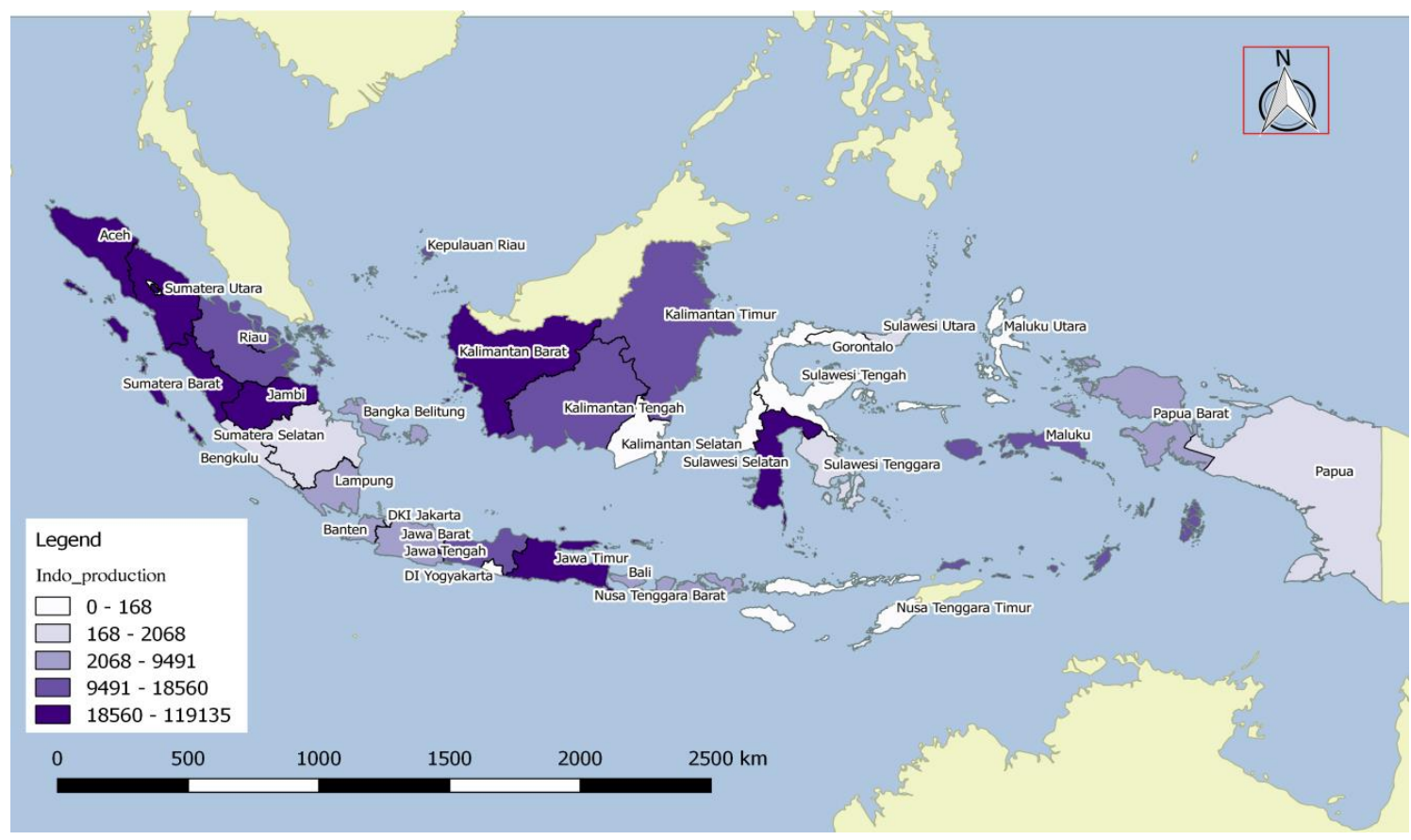

Figure 1. Shrimps' Capture Production (metric tons) by Provinces, 2017

Source: Author's calculation (2020) (calculated based on BPS-Statistic Indonesia (2020))

Despite the fact that MSC industry negatively impacted seafood implementation may hamper seafood exporters from DCs, the restriction on food safety standards has existed in the liberalized shrimp market for a couple of decades. For example, in 1977, the introduction of mandatory HACCP (Hazard Analysis Critical Control Point) in the United States for the seafood imports from DCs, including Indonesia. This policy on food standards is more likely viewed as "standard-as-barriers" than "standard-as catalysts" (Wati, WenI, \& Mustadjab, 2013). Yi and Reardon (2015) identified that only a small number of fishers could participate in the international markets remains a major 
barrier to addressing stimulant use of food safety standards. They argue that large firms are more efficient in allocating input production than small fishers. They can access factor markets and extensive social networks which operate close to the cost frontier. In contrast, small fisheries have difficulty coping with the market risks. It is not only because of the economics of scale but also their lack of capabilities to participate in social networking.

Regarding the current international trade of Indonesian shrimp commodity, Figure 2 displays the volume of monthly shrimp export in 2017. The Fish Quarantine and Inspection Agency (Balai Karantina Ikan dan Pengendalian Mutu Jakarta-BKIPM) has reported this data. This agent is the official Indonesian government intervention to ensure the health, quality, and safety of fishery products for export and import. It is a competent authority that gives out a certificate of fish and fishery products that meet the health requirements. It also implements control system on the prevention of export or import product that does not meet consumer demands

2 Notably, several types of shrimp are captured and farmed in Indonesia, including rainbow shrimps, tiger cat shrimps, yellow shrimps, endeavor shrimps, giant tiger prawn, and Indian requirements. This effort is applied to minimize the rejection rate from trading partners countries.

Figure 2 displays that Banana prawn (Fenneropenaeus merguiensis), White or stork Shrimps (Penaeus indicus) and Vannamei Shrimp (Litopenaeus vannamei) are the main types of shrimps that are produced and exported through quality monitoring by this institutio ${ }^{2}$. About $13 \%$ of the shrimp's export was produced from fishing and $87 \%$ of the export volume was harvested from aquaculture. Harvest from both fishing and farm shrimps will range from the late August to the end of October, indicating that the export activities are intense during this period. The annual report of fisheries export shows that the fresh and frozen shrimp volumes are dominant compared to processing or canned shrimps. Indeed, the valueadded of processed food is much higher than that of raw food. In the case of Indonesia, better infrastructure is required to strengthen the value chain of this industry to the global market (Ministry of Marine Affairs and Fisheries, 2019).

shrimp. Other types of shrimp were exported and passed the quality test from other agencies in Medan, Ambon, Surabaya, Semarang, and Manado. 


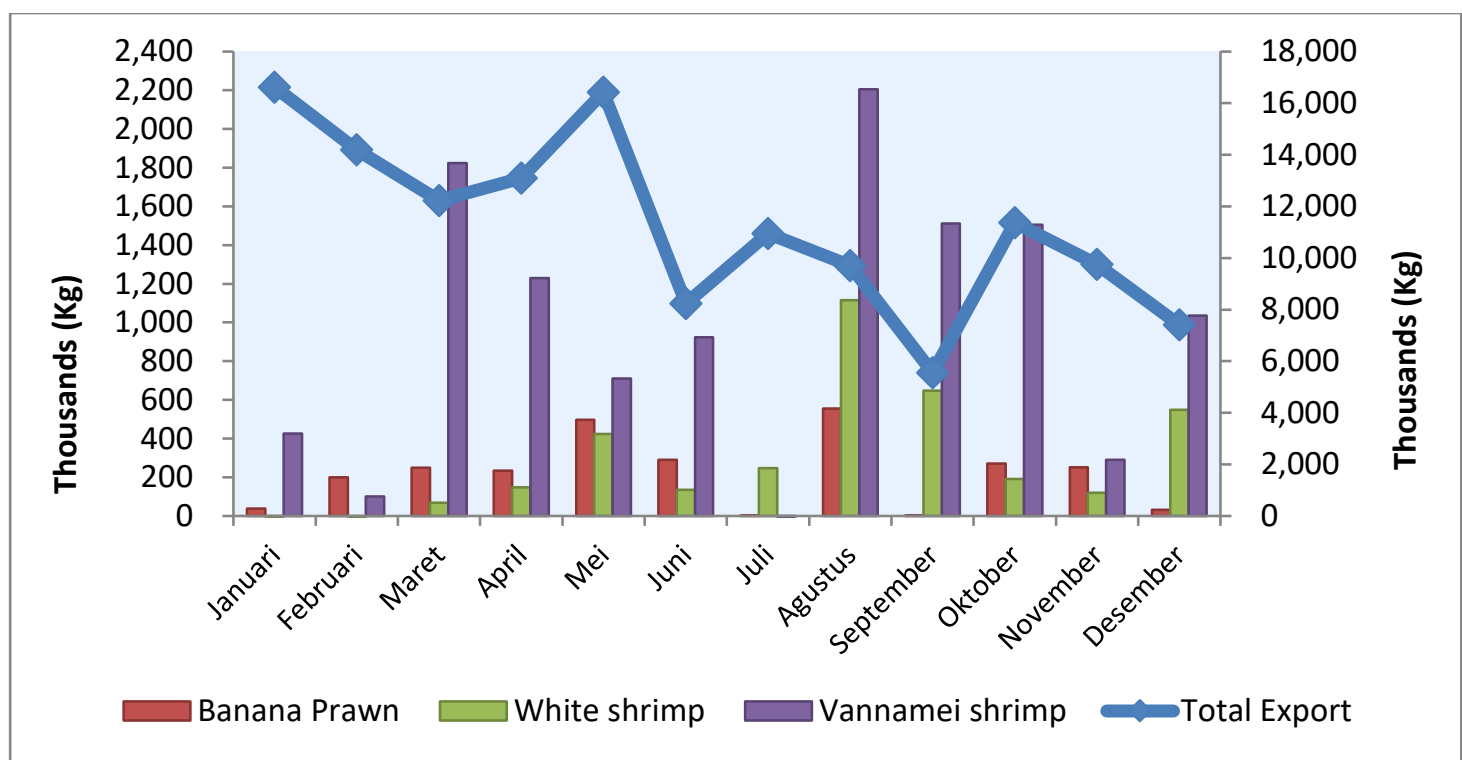

Figure 2. Volume Export Shrimp (monthly), 2017

Source: Author's calculation (2020) (calculated based on BKIMP Jakarta, 2018)

To date, the overall exports of shrimp in most countries in Asia declined, particularly in Thailand and Vietnam (Food and Agriculture Organization (FAO), 2019; Ministry of Marine Affairs and Fisheries, 2019). This fall in exports could be due to lower import demand from the USA, EU, and Japanese markets. The top players among the shrimp exporters are China and Ecuador as a new emerging competitor. However, Indonesia remains one of the top three exporters and the world's second largest shrimp producers (Food and Agriculture Organization (FAO), 2019). The United States is the main trading partner for Indonesia shrimp products. Accordingly, Indonesia has enjoyed zero export tariffs to this country. Moreover, the import duty to this country is the lowest rate among others export destination countries. In importers' view, large economic size and mutual agreement between the USA and the exporter countries are the key to good bilateral trade (Chenyi He, 2013).

\section{The Cost-Benefit Analysis of MSC} Project on Wild-Caught Shrimps

The purpose of this paper is to give a brief understanding to the public about cost-benefit analysis by including the cost of MSC certification. It can be a simple, practical application for those entities who are willing to invest in this industry. To better understand whether investing in MSC is undertaken or not, it is necessary to consider aspects of an international trade agreement. Table 1 describes the baseline condition of international trading between Indonesia 
and four importer countries. The number of shrimp catchers is about over 1 million households. Most of the products were exported as frozen food because of the high demand for this package form. However, the processed shrimp, such as packaging in canned, is more valuable than fresh and frozen products (Ministry of Marine Affairs and Fisheries, 2019). The majority demand for Indonesian shrimps' product is the USA market by $72 \%$ of market share. It is followed by Japanese, Europe, and China market with $21 \%, 5 \%$ and $2 \%$ respectively.

Table 1. International Trading of Indonesian Shrimp Capture, 2018

\begin{tabular}{|c|c|c|c|c|}
\hline Items & Europe & USA & Japan & China \\
\hline Tariff & $6 \%$ & $0 \%$ & $0 \%$ & $0 \%$ \\
\hline Export Tax & $5 \%$ & $5 \%$ & $5 \%$ & $5 \%$ \\
\hline Import Duty & $12 \%$ & $4 \%$ & $4.5 \%$ & $9 \%$ \\
\hline $\begin{array}{l}\text { Volume of Production to } \\
\text { export (tons) }\end{array}$ & 54.67 & 795.51 & 231.57 & 23.48 \\
\hline $\begin{array}{l}\text { Number of fishers or } \\
\text { household }\end{array}$ & & & & \\
\hline
\end{tabular}

Source: Ministry of Marine Affairs and Fisheries (2019), TRAIN database and UNCTAD (2018)

In 2009, Indonesia enjoyed GPS (General Preferential System) from European Community that implies reducing export tariffs. Before this agreement, Indonesia's fisheries producers have imposed an export tax of almost $21 \%$. In 2018, the EU tariff for all the classes of shrimp products was about $6 \%$ and EU duties on imports from Indonesia rate is $12 \%$. In contrast, exporting shrimps and prawns to the USA, Japan, and China markets have been waived under the bilateral agreement (Most Favorable Nations) between Indonesia and those countries. This information is important to consider which countries are the primary export destinations while maintaining consumer demand.
The following discussion provides an exemplary analysis of how to conduct cost and benefit analysis MSC project in Indonesia. These calculations do not refer to any project that is running now. To the best of our knowledge, no entity in Indonesia currently proposes MSC certification for shrimp product from Indonesia. Table 2 provides detail of the capital and operational costs of the MSC project. The assuming on the cost components of the project were resemble previous studies form other countries that available in many literatures (Campbell \& Richard P.C. Brown, 2016; Glynn, 2010; Vestergaard, Stoyanova, \& Wagner, 2010). We confront and clarify the information from the literature to Indonesian expertise on 
shrimp capture production from MMAF and WWF. These costs are spent for catching 1,500 metric tons $(\mathrm{mt})$ of banana prawn and white shrimps per annum. The project will take one year to establish and will run for a further 20 years, operating at $30 \%$ capacity in year
$1,70 \%$ in year two and at full capacity thereafter. The company uses an $8 \%$ discount rate (real) for investment decision making, and it is interested in knowing the sensitivity of the results at $4 \%, 8 \%, 12 \%$ and $20 \%$ discount rates.

Table 2. Capital cost and operational cost of the project

\begin{tabular}{lrr}
\hline \multicolumn{1}{c}{ Costs } & $\begin{array}{c}\text { Market Prices } \\
\text { (IDR millions) }\end{array}$ & $\begin{array}{c}\text { Salvage Values } \\
(\%)\end{array}$ \\
\hline A. Capital Cost & $25,000,-$ & $20 \%$ \\
Vessels & $7,500,-$ & $80 \%$ \\
Land \& Improvements & $10,000,-$ & $50 \%$ \\
Buildings \& Facilities & $20,000,-$ & $15 \%$ \\
Equipment & $15,000,-$ & $100 \%$ \\
Working Capital & & \\
B. Operating Costs & $4,000,-$ & \\
Labour & $3,000,-$ & \\
Materials & $200,-$ & \\
Maintenance & $4,800,-$ & \\
Fuel & $300,-$ & \\
Electricity & $1,000,-$ & \\
Miscellaneous & & \\
Sources:Ministry of Marine Affairs and Fisheries (2019), and in-depth interview with some experts, 2020 \\
$\quad$ (modified and calculated by authors based on information on financial market in 2018, 2021)
\end{tabular}

We assume that the company plans to take a loan from the domestic bank by $60 \%$ to finance the cost of vessel, land and improvements, buildings and facilities, equipment and working capital at a real interest rate of $12 \%$ with the loan repayable over ten years. The value of the vessel will depreciate over ten years, buildings and facilities over 20 years, and equipment over ten years for tax purposes. Replacement costs will be incurred in year 11 of the project: $25 \%$ of the initial cost of the vessel and $50 \%$ of the initial cost of equipment. The salvage values are the market value of the asset sold in Indonesia, and recipients are treated as income for tax purposes. Company tax is levied on taxable income, defined as revenue net of export tax and duty, less operating cost, interest, and depreciation expenses. In Years 1 and 2, all operating costs, except insurance, will be incurred at $30 \%$ and $70 \%$ of capacity costs respectively. In subsequent years, operating costs are at full capacity level irrespective of the volume of catch. The wage bill 
accounted for local labor is $100 \%$, and they pay an average income tax rate of $10 \%$. To simplify our calculation on costbenefit analysis, we assume that shrimps are exported as frozen food. Considering that Japanese and Chinese markets are not required an MSC certificate as mandatory for imported seafood from developing country, we exclude these countries from our analysis.

Table 3. Summary of total cost and output

\begin{tabular}{|c|c|c|c|c|c|}
\hline \multirow[t]{2}{*}{ No } & \multirow[t]{2}{*}{ Items } & \multicolumn{2}{|c|}{ USA } & \multicolumn{2}{|c|}{ EU } \\
\hline & & $\begin{array}{l}\text { Without } \\
\text { MSC }\end{array}$ & With MSC & $\begin{array}{l}\text { Without } \\
\text { MSC }\end{array}$ & With MSC \\
\hline 1 & Cost of Capital (IDR millions pa) & $77,500,00$ & $77,500,00$ & $77,500,00$ & $77,500,00$ \\
\hline 2 & Operating cost (IDR millions pa) & $13,300,00$ & $13,300,00$ & $13,300,00$ & $13,300,00$ \\
\hline 3 & Taxes and Duties (IDR millions) & $8,701.95$ & $8,701.95$ & $2,674.95$ & $2,674.95$ \\
\hline 4 & Cost of MSC (IDR mmillions) & 0 & $9,860.19$ & 0 & $9,257.49$ \\
\hline 5 & Annual Export (ton/year) & 750 & 750 & 225 & 225 \\
\hline \multirow[t]{2}{*}{6} & Price & & & & \\
\hline & Frozen (IDR millions/ton) & 110.60 & 110.60 & 170.94 & 170.94 \\
\hline
\end{tabular}

Sources: Ministry of Marine Affairs and Fisheries (2019), Marine Stewardship Council (2021), International Trade Centre (ITC) (2020) (modified and calculated by Author's, 2021

Table 3 summarizes the total cost and output that we expect from this MSC project. It assumes that export distribution includes $50 \%$ for USA market, $15 \%$ for EU market, and 35\% for domestic and other potential markets. Following previous studies from other DCs, the maximum total cost for MSCcertified is less than or equal to $10 \%$ out of total cost of production (Lallemand,
Bergh, Hansen, \& Purves, 2016). Even though the cost may vary and fluctuate across time, but at this proportion, the incurred cost is feasible proportion that fisheries can afford to finance. Some determinants influencing MSC cost are the fluctuation on exchange rate, and other exogenous factors such as the change of government policies and climatic events (Howes, 2008). 
Table 4. Alternative Options

\begin{tabular}{|c|c|c|}
\hline Option & Market & Requirement \\
\hline Option 1 & $\begin{array}{l}\text { United State of } \\
\text { America }\end{array}$ & $\begin{array}{l}\text { No MSC and no concessions (duties and export tax paid by } \\
\text { company) }\end{array}$ \\
\hline Option 2 & & No MSC and no duties and export tax. \\
\hline Option 3 & & $\begin{array}{l}\text { MSC and } 15 \% \text { increases in export volume and no duties and export } \\
\text { tax. }\end{array}$ \\
\hline Option 4 & $\begin{array}{l}\text { European } \\
\text { Countries }\end{array}$ & $\begin{array}{l}\text { No MSC and no concessions (duties and export tax paid by } \\
\text { company) }\end{array}$ \\
\hline Option 5 & & No MSC and no duties and export tax. \\
\hline Option 6 & & $\begin{array}{l}\text { MSC and } 15 \% \text { increases in export volume and no duties and export } \\
\text { tax. }\end{array}$ \\
\hline
\end{tabular}

Sources: Author's (2021)

A company seeks a mutual benefit from bilateral and multilateral trade agreements between the Indonesian government and its trading partners. It is suggested that the strengthening global value chain (GVC) and free trade agreements (FTA) with the United State and European countries reduce trade cost and supporting infrastructure for trade facilitations. Both markets offer benefit for Indonesia seafood export, the EU offer higher prices, while the USA ease trade restriction and creates higher demand for Indonesian seafood.

The company also seeking for exemption from Indonesia export tax levied on the value of shrimp sold overseas. This policy is accordance to the law No. $7 / 1994$ that is aimed to create markets for export. Accordingly, the government supports such company which has pay attention to invests and applies in sustainable fisheries, by deducting on their income tax and other potential taxes. The company may apply to exempt from duties on imports of vessels, working capital and material; exemption from fuel tax; and exemption from VAT (Value Added Tax) on miscellaneous items. To accommodate the variety of alternatives, open to the government and company regarding the proposal of MSC investment, Table 4 provides all the considered options. In the option 3 and 6 , we assume that by labeling their product, the company will increase its export by $15 \%$. 
Table 5. Cost-Benefit Analysis for Each Component

\begin{tabular}{|c|c|c|c|c|c|c|c|}
\hline $\begin{array}{c}\text { Discount } \\
\text { Rates } \\
\text { (for NPV) }\end{array}$ & Option & $4 \%$ & $8 \%$ & $12 \%$ & $20 \%$ & IRR & Rank \\
\hline \multicolumn{8}{|c|}{ A. Project (Market) Analysis (IDR in millions) } \\
\hline \multirow[t]{3}{*}{ USA } & Option 1 & $729,381.45$ & $487,730.25$ & $339,542.13$ & $178,745.79$ & $54.94 \%$ & 5 \\
\hline & Option 2 & $815,528.12$ & $549,030.35$ & $385,434.54$ & $207,710.27$ & $60.32 \%$ & 2 \\
\hline & Option 3 & $849,122.56$ & $572,660.08$ & $402,914.80$ & $218,478.97$ & $62.10 \%$ & 1 \\
\hline \multirow[t]{3}{*}{ EU } & Option 4 & $502,109.01$ & $327,055.63$ & $220,118.08$ & $104,541.91$ & $41.53 \%$ & 6 \\
\hline & Option 5 & $739,347.55$ & $495,312.92$ & $345,624.48$ & $183,132.69$ & $56.19 \%$ & 4 \\
\hline & Option 6 & $751,725.89$ & $503,976.60$ & $352,010.20$ & $187,049.63$ & $56.85 \%$ & 3 \\
\hline \multicolumn{8}{|c|}{ B. Private Analysis (IDR in millions) } \\
\hline \multirow[t]{3}{*}{ USA } & Option 1 & $548,078.10$ & $370,080.88$ & $261,935.55$ & $146,057.70$ & $80.41 \%$ & 5 \\
\hline & Option 2 & $612,688.11$ & $416,055.96$ & $296,354.86$ & $167,781.06$ & $89.45 \%$ & 2 \\
\hline & Option 3 & $637,883.94$ & $433,778.26$ & $309,465.06$ & $175,857.59$ & $92.27 \%$ & 1 \\
\hline \multirow[t]{3}{*}{ EU } & Option 4 & $377,623.78$ & $249,574.92$ & $172,367.52$ & $90,404.79$ & $58.98 \%$ & 6 \\
\hline & Option 5 & $555,552.68$ & $375,767.89$ & $266,497.32$ & $149,347.87$ & $82.89 \%$ & 4 \\
\hline & Option 6 & 564836.43 & 382265.64 & 271286.61 & 152285.58 & $83.94 \%$ & 3 \\
\hline \multicolumn{8}{|c|}{ C. Efficiency Analysis (IDR in millions) } \\
\hline \multirow[t]{3}{*}{ USA } & Option 1 & $611,769.50$ & $412,456.37$ & $290,865.80$ & $159,177.71$ & $61.94 \%$ & 5 \\
\hline & & $617,420.97$ & $416,275.45$ & $293,559.67$ & $160,649.59$ & $61.96 \%$ & 3 \\
\hline & Option 3 & $748,584.34$ & $505,978.45$ & $357,719.58$ & $197,095.76$ & $65.69 \%$ & 1 \\
\hline \multirow[t]{3}{*}{ EU } & Option 4 & $611,752.10$ & $412,439.61$ & $290,849.64$ & $159,162.62$ & $61.93 \%$ & 6 \\
\hline & Option 5 & $617,403.56$ & $416,258.69$ & $293,543.50$ & $160,634.51$ & $61.95 \%$ & 4 \\
\hline & Option 6 & $740,472.61$ & $500,425.95$ & $353,744.11$ & $194,831.84$ & $65.47 \%$ & 2 \\
\hline \multicolumn{8}{|c|}{ D. Referent Group Analysis (IDR in millions) } \\
\hline \multirow[t]{3}{*}{ USA } & Option 1 & $168,150.84$ & $122,473.64$ & $94,986.26$ & $65,616.63$ & $49.17 \%$ & 4 \\
\hline & Option 2 & $146,069.55$ & $106,567.79$ & $82,920.53$ & $57,783.31$ & $50.64 \%$ & 2 \\
\hline & Option 3 & $148,952.57$ & $108,586.00$ & $84,408.29$ & $58,696.03$ & $52.08 \%$ & 1 \\
\hline \multirow[t]{3}{*}{ EU } & Option 4 & $185,964.99$ & $134,903.75$ & $104,088.83$ & $71,086.96$ & $43.70 \%$ & 6 \\
\hline & Option 5 & $127,007.00$ & $93,121.67$ & $72,951.85$ & $51,623.83$ & $47.28 \%$ & 5 \\
\hline & Option 6 & $130,216.49$ & $95,368.62$ & $74,608.33$ & $52,640.14$ & $47.82 \%$ & 3 \\
\hline
\end{tabular}

Sources: Author's Calculation (2021)

This section presents the four the NPV and IRR calculations, the value components of the cost-benefits analysis, which is examined separately for each option. Table 5 summarizes the NPV and IRR for each option for both preferential markets. The unit values of NPV are presented in millions of Rupiah. The detail for this information can be provided upon request. From the market perspective (panel A), option 3 is preferred over the other option, followed by option 2 and option 3 on the second and third ranks. This is the case for both of NPVs are positive, but it decreases when a discount rate of $20 \%$ is used.

Similarly, option 3 is the most favored option for company. This is because the low tariff and the high demand outweigh the benefits of exporting to USA market. Meanwhile, the benefits of not having to pay export tax, import duty and profit tax from European market is offset by the low demand of export, although the prices of seafood in this market are significantly 
higher than that of from USA market. Deciding on the rank 2 and rank 3 clearly explains that without considering conservation, a company has benefit from the exemption of tariff barrier to trade with USA over the benefit from environmental labeling of their exported seafood to EU.

Importantly, it has been noticed that efficient allocation of resources across all groups impacted by MSC project reveal that the MSC project for the USA ranking is slightly higher than the European options. Of course, this analysis does not take into account any distributional effects regarding who would receive the benefits and who would bear the costs.

As would have expected option 4 is the lowest ranked for all analysis, when the company should pay all trade cost, although the costs come from non-tariff barrier is not included in the analysis. It is suggested that trade costs are matter for Indonesian seafood entering international trade. To put it another way, in the referent group analysis, the government revenue from income taxes rises by about $13 \%$ at an $8 \%$ discount rate, despite the potential loss of income from export taxes. This is because the MSC label is expected to increase shrimp demand by $15 \%$. All the options in this analysis have no effect on labor benefits. At an $8 \%$ discount rate whether the company invests in the MSC project, the unskilled laborers receive a constant benefit.

Notably, the NPV rankings and IRRs value are consistent for all discount rates with decreasing value when the discount rates are much higher than the selected rate $(8 \%)$. Based on the data from those analysis, option 1 and option 4 that exhibit business as usual are clearly rejected. Those options may increase government revenues, but they offer no incentives to company, and they ranked last, particularly in the private analysis.

The study's findings have flaws in some points. For instance, the study does not take into account shadow prices. Shadow prices can emerge because of currency fluctuation and costs of environmental damages. The dynamic changes in the exchange rate have an impact on the prices and output. Prices are used as an average in 2018 , and they must be fixed for 20 years. In addition, because the goal of this project is to restore marine resources, the environmental damage has been minimized, though it is possible that the damage might have occurred during the project. 


\section{CONCLUSION AND POLICY RECOMENDATION}

Many programs were developed prior to the launch of the MSC program in 2010. The programs are intended to promote standardization and good fisheries practices for shrimp catchers. In this regard, the implementation of MSC for developing-country seafood products is still being debated. The debate is about whether this ecolabeling barrier would benefit shrimp catchers, or it is simply another way to protect domestic producers in the developed countries.

Overall, the findings from the project, private, efficiency allocation and referent group analyses support the belief that is adhering to the MSC standard benefits all impacted groups. In addition, the Indonesian government could increase income from corporate taxes by $13 \%$. Meanwhile, for other groups such as labors and communities, the decision to invest in the MSC project has no beneficial effects.

Based on our analysis on the MSC project of shrimp capture, the USA market is still the most potential market for eco-labeled shrimps. This country offers a lower tariff and duties, and the consumer demand on Indonesian shrimps is enormous. The easing trade restriction between two countries indicates the effectiveness of the existing free trade agreement. This mutual benefit may exist whether Indonesian producers have followed MSC-standard or not, but the potential benefits is much higher if the Indonesian company complies with the MSC procedures.

A similar conclusion was reached for the European market. The market share of Indonesian shrimps in the European market was quite low compared to that in other Indonesia major trading partners. However, this market offers the highest prices. It is essential to meet the requirements for food safety and quality handling when exporting shrimps to grab this opportunity. The potential benefits of international trade can be enhanced by reducing trade restrictions and establishing a non-MFN agreement between two countries.

In conclusion, under certain condition, adopting the MSC standard may improve the welfare of the referral group and company. The prerequirement conditions include a stable discount rate at $8 \%$ or lower for the next twenty years. There is a high likelihood that export volume will increase at least by $15 \%$. This expectation may happen if 
the current stock of live shrimp in the Indonesian seas is still abundant. Thus, the study suggests that the Indonesian government encourages and facilitates fishing companies to follow and comply with the MSC standard. It is also expected that the government opens some opportunities for small shrimp catchers to participate in the project.

At last, we suggest that further research on this topic be undertaken to provide better analysis by overcoming some weaknesses of this study. The caveat of this study was not included shadow price analysis, such as the cost of sea pollution and the fluctuation of the exchange rate during the period of analysis. More rigorous analysis on risk assessment and environmental damage may enrich this study.

\section{ACKNOWLEDGEMENT}

We would like to express our gratitude to the Economic Research Center, the Indonesian Institute for Sciences, the Ministry of Marine Affairs and Fisheries (MMAF), and the World Wildlife Fund, which give fruitful discussion and support to this work. We also like to thank Nurlia Listiani, Dhani Agung Dharmawan and Diah Setiari Suhodo for their contribution during the fieldwork.

\section{REFERENCES}

Adler, M. D., \& Posner, E. A. (1999). Rethinking Cost-Benefit Analysis. The Yale Law Journal, 109(2), 165-247.

Aquaculture Stewardship Council. (2017). Tokyo seminar gathers stakeholders interest.

Bellchambers, L. M., Phillips, B. F., \& PérezRamírez, M. (2016). From certification to recertification the benefits and challenges of the Marine Stewardship Council (MSC): A case study using lobsters. Fisheries Research, 182, 88-97. doi:10.1016/j.fishres.2015.08.029

Blandon, A., \& Ishihara, H. (2021). Seafood certification schemes in Japan: Examples of challenges and opportunities from three Marine Stewardship Council (MSC) applicants. Marine Policy, 123. doi:10.1016/j.marpol.2020.104279

BPS-Statistic Indonesia. (2020). Produksi Perikanan Tangkap Menurut Provinsi dan Jenis Penangkapan 2017. from BPSStatistic Indonesia

Campbell, H. F., \& Richard P.C. Brown. (2016). Cost-benefit analysis: financial and economic appraisal using spreadsheets. London [England], New York [USA] Routledge.

Chenyi He , K. K. Q. H. H. W. (2013). Determinants of shrimp importation into the USA: an application of an augmented gravity model. Journal of Chinese Economic and Business Studies(3), 219228.

doi:10.1080/14765284.2013.814466

Christian, C., Ainley, D., Bailey, M., Dayton, P., Hocevar, J., LeVine, M., . . Jacquet, J. (2013). A review of formal objections to Marine Stewardship Council fisheries certifications. Biological Conservation, 161, 10-17. doi:10.1016/j.biocon.2013.01.002

Food and Agriculture Organization (FAO). ( 2019). Country assessment gender of agriculture and the rural sector in Indonesia. Retrieved from Jakarta: 
Gillett, R. (2008). Global study of shrimp fisheries (Vol. 475): Food and Agriculture Organization of the United Nations Rome.

Glynn, S. (2010). Eco-labelling: The new cost of doing business in the seafood sector. ProQuest Dissertations Publishing, Retrieved from http://anu.summon.serialssolutions.com (Dissertation/Thesis)

GRO. (2020). Ratusan Nelayan Tuna Pulau Buru Raih Sertifikat Ecolabelling MSC. Harian Ekonomi Neraca.

Hatanaka, M. (2010a). Certification, Partnership, and Morality in an Organic Shrimp Network: Rethinking Transnational Alternative Agrifood Networks. World development, 38(5), 706-716.

doi:10.1016/j.worlddev.2009.11.001

Hatanaka, M. (2010b). Governing sustainability: examining audits and compliance in a third-party-certified organic shrimp farming project in rural Indonesia. Local Environment, 15(3), 233-244.

doi:10.1080/13549830903575588

Howes, R. (2008). The Marine Stewardship Council Programme. In T. Ward \& B. Phillips (Eds.), SEAFOOD Ecolabelling (pp. 81-105). Oxford, UK: WileyBlackwell.

International Trade Centre (ITC). (2020). Yearly Trade by Commodity Statistics 2001 - 2019.

Kasim, K. (2019). Fishery Performance Indicators (FPIs) and Production Analysis: What Works Before and After the Ban of Cantrang Trawl Fishing in the Java SeaIndonesia. ProQuest Dissertations Publishing, (Dissertation/Thesis)

Lajus, D., Stogova, D., \& Keskitalo, E. C. H. (2018). The implementation of Marine Stewardship Council (MSC) certification in Russia: Achievements and considerations. Marine Policy, 90, 105114. doi:10.1016/j.marpol.2018.01.001

Lallemand, P., Bergh, M., Hansen, M., \& Purves, M. (2016). Estimating the economic benefits of MSC certification for the South African hake trawl fishery. Fisheries Research, 182, 98-115. doi:10.1016/j.fishres.2016.02.003

Le Manach, F., Jacquet, J. L., Bailey, M., Jouanneau, C., \& Nouvian, C. (2020). Small is beautiful, but large is certified: A comparison between fisheries the Marine Stewardship Council (MSC) features in its promotional materials and MSCcertified fisheries. Plos One, 15(5). doi:10.1371/journal.pone.0231073

Marine Stewardship Council. (2021). Fishery certification guide Fisheries. Retrieved from https://www.msc.org/forbusiness/fisheries/fishery-certificationguide

Melser, D., \& Robertson, P. E. (2005). Ecolabelling and the Trade-Environment Debate. World economy, 28(1), 49-62. doi:10.1111/j.1467-9701.2005.00674.x

Peraturan Menteri Kelautan dan Perikanan: Bans the use of trawls and seine nets for catching fish, (2015).

Ministry of Marine Affairs and Fisheries. (2019). Laporan Tahunan 2018. Retrieved from Jakarta:

Ponte, S. (2012). The Marine Stewardship Council (MSC) and the Making of a Market for 'Sustainable Fish'. Journal of Agrarian Change, 12(2-3), 300-315. doi:10.1111/j.1471-0366.2011.00345.x

Resosudarmo, B. P., \& Kosadi, E. (2018). Illegal Fishing War: An Environmental Policy during the Jokowi Era? Journal of Southeast Asian Economies, 35(3), 369385. doi:10.1355/ae35-3d

Seekao, C., \& Pharino, C. (2018). Costbenefit analysis of shrimp farming's flood risk reduction strategies in Thailand. Journal of Flood Risk Management, 11, S805-S816. doi:10.1111/jfr3.12259

Toonen, H. M., \& Mol, A. P. J. (2013). Putting sustainable fisheries on the map? Establishing no-take zones for North Sea plaice fisheries through MSC certification. Marine Policy, 37((C)), 294-304.

Tsutsui, I., Songphatkaew, J., Meeanan, C., Aue-umneoy, D., Sukchai, H., Pinphoo, P., . . Hamano, K. (2015). Co-culture 
with Chaetomorpha sp. enhanced growth performance and reduced feed conversion ratio of the giant tiger prawn, Penaeus monodon. International Aquatic Research, $7(3)$, doi:10.1007/s40071-015-0103-0 193-199.

UNCTAD. (2018). Handbook of Statistics.

Vestergaard, N., Stoyanova, K. A., \& Wagner, C. (2010). Cost-Benefit Analysis of the Greenland Offshore Shrimp Fishery. Acta Agriculturae Scandinavica, 8, 98.

Wati, L. A., Wen-I, C., \& Mustadjab, M. M. (2013). Competitiveness of Indonesian Shrimp Compare with Thailand Shrimp in Export Market. Wacana 16(1), 24-31.

Wessells, C. R., Johnston, R. J., \& Donath., H. (1999. ). Assessing consumer preferences for eco-labelled seafood: the influence of species, certifier and household attributes. American journal of agricultural economics, 81, 1084-1089.
Wijen, F., \& Chiroleu-Assouline, M. (2019). Controversy Over Voluntary Environmental Standards: A Socioeconomic Analysis of the Marine Stewardship Council. Organization \& Environment, 32(2), 98-124. doi:10.1177/1086026619831449

World Wildlife Fund. (2015). PENANGKAPAN UDANG RAMAH LINGKUNGAN: Dengan Alat Tangkap Jaring Tiga Lapis (Trammel Net). Retrieved from Jakarta, Indonesia:

Yi, D., \& Reardon, T. (2015). Allocative Efficiency of Agrifood Traders: Shrimp Traders in Indonesia. Bulletin of Indonesian Economic Studies: Transformation of the Indonesian Agrifood System and the Future beyond Rice, 51(3), 405-423. doi:10.1080/00074918.2015.1107676 
